African Crop Science Journal by African Crop Science Society is licensed under a Creative Commons Attribution 3.0 Uganda License. Based on a work at www.ajol.info/ and www.bioline.org.br/cs DOI: https://dx.doi.org/10.4314/acsj.v28i4.8

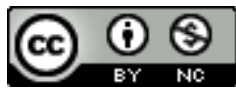

\title{
DETERMINANTS OF CONTRACT FARMING FOR SMALLHOLDER SUNFLOWER PRODUCERS IN NORTHERN UGANDA
}

\author{
J. AKUMU, W. ODONGO and B. MUGONOLA
}

Department of Agribusiness and Rural Development, Gulu University, P. O. Box 166, Gulu, Uganda Corresponding author: julietakumu53@gmail.com

(Received 28 February 2020; accepted 13 November 2020)

\begin{abstract}
Contract farming is a form of vertical coordination, largely aimed at correcting market failures associated with spot markets that arise due to imperfect information. The objective of this study was to assess the determinants of farmer engagement in sunflower (Helianthus annus L.) contracts in northern Uganda. Stratified random sampling was used to select 150 contracted and 150 non-contracted sunflower farmers in Oyam District, from where primary data were collected using a semi-structured questionnaire. A Logistic regression model was used to examine the factors that influenced farmer participation in contract farming. The major determinants of participation in contract farming by smallholder farmers were age $(\mathrm{P}<0.1)$, sunflower production experience $(\mathrm{P}<0.01)$, access to credit $(\mathrm{P}<0.01)$ and unit produce price $(\mathrm{P}<0.01)$. Collaborative efforts by all parties engaged in contracting arrangements are necessary to negotiate a minimum price with the farmers, with a possibility to renegotiate whenever the market price is above the set price. The study pointed out that improvement in rural roads to enhance transportation of produce to mini-store is vital in driving sunflower contract farming in Oyam district. Therefore, policies aimed at improving rural roads are urgently needed.
\end{abstract}

Key Words: Age, Helianthus annus, vertical coordination

\section{RÉSUMÉ}

L'agriculture contractuelle est une forme de coordination verticale, qui vise principalement à corriger les défaillances du marché associées aux marchés qui surviennent avec d'informations imparfaites. L'objectif de cette étude était d'évaluer les déterminants de l'engagement des agriculteurs dans les contrats de tournesol (Helianthus annus L.) dans le Nord de l'Ouganda. Un échantillonnage aléatoire stratifié a été utilisé pour sélectionner 150 cultivateurs de tournesol sous contrat et 150 sans contrat dans le district d'Oyam, à partir desquels les données primaires ont été collectées à l'aide d'un questionnaire semi-structuré. Un modèle de régression logistique a été utilisé pour examiner les facteurs qui ont influencé la participation des agriculteurs à l'agriculture contractuelle. Les déterminants principaux de la participation à l'agriculture contractuelle des petits exploitants agricoles étaient l'âge $(\mathrm{P}<0,1)$, l'expérience de production de tournesol $(\mathrm{P}<0,01)$, l'accès au crédit $(\mathrm{P}<0,01)$ et le prix unitaire des produits $(\mathrm{P}<0,01)$. Les parties engagées dans des accords contractuels sont nécessaires pour 
négocier un prix minimum avec les agriculteurs, avec la possibilité de renégocier chaque fois que le prix du marché est supérieur au prix fixé. L'étude a souligné que l'amélioration des routes rurales pour améliorer le transport des produits vers les mini-magasins est essentielle pour stimuler l'agriculture contractuelle de tournesol dans le district d'Oyam. Par conséquent, des politiques visant à améliorer les routes rurales sont nécessaires de toute urgence.

Mots Clés: Âge, Helianthus annus, coordination verticale

\section{INTRODUCTION}

The rise in contract farming of oil crops, such as sunflower (Helianthus annus L.), in Uganda has been due to the need to strengthen vertical coordination between producers and agribusiness firms. The rising importance of contract farming in the country has largely been due to the changing global environment, where competition, consumer demands, technology, government policies and agricultural systems have been taking the centre stage (Kokeyo, 2013). Contract farming has successfully enabled smallholder farmers in developing countries to commercialise their farming operations, by creating market linkages, both domestic and international (Prowse, 2012). A number of case studies on agricultural commodities, such as tea, oilseeds, sugarcane, cotton, oil palm and rice, have shown that smallholder farmers can benefit from contract farming in various ways, including access to production inputs and to output markets, market development and other intangible benefits (Eaton et al., 2001).

Contract farming is defined as an agreement between a farmer and a purchaser, usually established in advance of the growing season for a specific quantity, quality and date of delivery of an agricultural output at a price or price formula fixed in advance (Prowse, 2012). It is a mechanism that enables agribusiness firms to outsource their raw materials from smallholder farmers, whom they often refer to as out-growers.

In Uganda, contract farming has been traditionally restricted to plantation crops such as sugarcane, tobacco and tea, where outgrowers implement production for large processing agribusiness firms such as Kakira Sugar Works, Sugar Corporation of Uganda Limited, Kinyara Sugar Works, Alliance one and Kasaku Tea Estate. However, other agribusiness firms, such as Nile Breweries, Uganda Breweries, Outspan Enterprises Limited, Mukwano Industries, Bee Natural Products, and Ugachick. Some co-operative unions have also extended contracts to smallholder farmers to ensure a continuous supply of critical inputs (Elepu and Nalukenge, 2016). Hence, the use of contract farming has spread to other crops such as quality protein maize, sorghum (Epuripur), organic products (cotton, coffee, sesame, etc.), oilseeds, rice, honey and poultry (FAO, 2001). Some of these contract farming schemes have been credited for playing a key role in increasing the profitability of crop farming, reducing marketing risks, and above all opening up new markets for non-traditional cash crops both at domestic and international levels (Minot, 2011).

Seed companies such as Equator Seeds Limited, Pearl Seeds Ltd, NASECO and Victoria Seeds Ltd also do contract farming with their seed out-growers in Uganda. These companies sign production agreements with seed out-growers; they provide them with seed, fertilisers and as well provide the outgrowers with extension services and working capital to help in maintaining quality of their seed crops while in the fields. However, while contract farming offers a huge opportunity for commercialising smallholder agriculture, smallholder farmers have reportedly experienced contractual problems in dealing with large agribusiness firms, resulting in smallholder farmers abandoning contract 
farming. Similarly, agribusiness firms have reportedly encountered contractual problems when dealing with some smallholder farmers that could have led to the exclusion of the latter from contract farming. In general, these contractual problems have been largely attributed to the failure of one of the parties to the honour the contractual obligations, either agribusiness firm or smallholder farmer (Minot, 2011). The objective of this study was to assess the determinants of farmer engagement in sunflower contract farming in northern Uganda.

\section{MATERIALS AND METHODS}

Study area. This study was conducted in Oyam district in northern Uganda; a region where sunflower contract farming is predominant. Oyam district is located between longitudes $32^{\circ} 23^{\prime} \mathrm{E}$ and latitudes $02^{\circ} 14^{\prime} \mathrm{N}$ and of the prime meridian.

Sampling procedure. A cross-sectional survey was used based on a multistage sampling procedure; whereby in the first stage, three sub-counties were purposively selected (Acaba, Myene and Loro sub counties), because of their predominance in sunflower production and the infiltration of contractual arrangement being undertaken. Secondly, five villages (Abala, Alok central, Abiloneni, Burara A and Burara B) were purposively selected, one village from Acaba sub county, two villages from Myene sub county and two villages from Loro sub county, based on their intensity in sunflower production under contract farming. In the third stage, a random sample of 300 smallholder farmers was selected in the three sub counties comprising 150 contracted (50 from each subcounty) and, 150 non-contracted (50 from each subcounty) smallholder growers of sunflower in the district. For this stage, a list of sunflower producers was obtained from sub-county extension staff of the study areas. Thereafter, a Table of Random Numbers was used to generate the sample size (Sarmah and Chakrabarty, 2016) in which contracted and non-contracted farmers with even numbers were picked for the sample.

Data analysis. The logit model was used to assess for factors influence on participation in contract farming. Logistic regression is a statistical technique used to examine the link between one or more independent variables with a dichotomous dependent variable (Chaturuka, 2013).

Participation in contract farming by sunflower farmers is a dichotomous or binary dependent variable, with the options of participation or non-participation in contract farming, the binary logistic regression model was deemed fit. Thus, we determined the relationship between sunflower contract farming participation and the various, socioeconomic, market and institutional factors using the logit model.

Model specification. The decision to participate in contract farming by sunflower producers can be modelled building on the Random Utility Theory Model Framework, mainly used to analyse adoption of innovations under the uncertainty (Pannell, 2003). A farmer will participate in a contract scheme if the expected benefits outweigh the costs of operating under contract. The decision to produce sunflower under contract is analysed based on binary choice models, which describe the probability of farmers' choice between the two mutually exclusive choices; participation or no participation basing on their evaluation on utilities obtained on these choices as put by (Wainaina et al., 2014). The utility function of a farmer, which is dichotomous denoting whether a farmer participated in sunflower contract farming would be presented by the equation 1 :

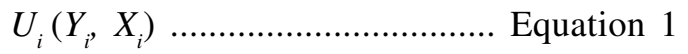

Where: 
$Y_{i}$ is a dichotomous variable denoting whether a farmer participated in sunflower contract farming.

The binary choices would, therefore, be 1 if yes and zero otherwise. $X_{i}$ is a vector of the explanatory variables. The actual utility level of each individual farmer $U_{i}$ is unobserved. The part of the utility function that is observed can be expressed as a function of the vector of exogenous variables and a vector of parameter $\beta$ to be estimated. The farmer would choose to adopt if such a choice implies a higher utility level compared to not adopting: That is:

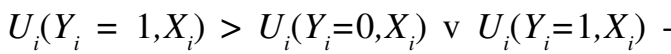
$U_{i}\left(Y_{i}=0, X_{i}\right)$ Equation 2

The probability of a farmer producing under contract is given by:

$\operatorname{Pr}\left(U_{i}<\beta^{r i}\right)$ Equation 3

This can be estimated using probit or logit models. A logit regression model was chosen in this case because of its ability to determine the effects of variables (Table 1) on the probability of farmer participation (Chaturuka, 2013). Therefore, the probability of participation in contract farming was estimated using the logit regression model to assigned socio-economic characteristics and other factors in this study. The model was estimated as:

$\operatorname{Pr}\left(Y_{i}=1\right)=\operatorname{Pr}\left(U_{i}<\beta^{x i}\right)=\beta^{\mathrm{xi}+u i} \ldots .$. Equation 4

Where:

$$
Y_{i}=1 \text { if } U_{m}>U_{n} \text { and } Y_{i}=0 \text { if } U_{m}<U_{n}
$$

Vector $X_{i}$ includes farm and household characteristics like, age, group affiliation, household size, etc., part of farmers utility which is unobserved is represented by an error term $\mu_{i}$.

The farmer chooses to produce under contract if the utility $U_{m}$ derived from participation in contract farming is greater than the utility $U_{n}$ derived from non-participation.

Empirical model. It is very likely that since firms initiate the contract (Dubbert, 2019), a farmer's participation in contract farming depends largely on firm's criteria rather than farmer's choice. In this context, the binary logit model was used to identify the determinants of farmers' participation in contract farming. In the model, participation or non-participation in contract farming was considered as a dependent variable, where a farmer who grew sunflower under contract was coded one (1), whereas a farmer who grew sunflower but not under contract was given a code zero (0). Several studies related to participation in this context (Opoku, 2012; Dubbert, 2019).

The empirical model suggested for this study was a logit regression model depicting the relationship between the variables as follows:

$Y=\beta_{0}+\beta_{I} X_{1}+\beta_{2} X_{2}+\beta_{3} X_{3}+e \ldots$. Equation 5

Where:

$Y=$ participation or non-participation in contract farming by the $i^{\text {th }}$ farmer;

$X_{i}, X_{2} \ldots X_{n}=$ Vector of determinants of participation,

$\beta_{0}=$ Constant coefficient,

$\beta_{l}, \beta_{2}, \ldots \beta_{n},=$ Regression coefficients to be estimated, and $e=$ error term.

\section{RESULTS AND DISCUSSION}

Participation in contract farming. Table 2 presents the results of the logit regression model on decision to participate in contract farming. It is clear that age, off-farm activity, access to credit, experience in sunflower production, household size, household labour size, distance to mini stores, unit price and 
TABLE 1. A priori expectation of explanatory variables in the logit model of sunflower contract farmers in northern Uganda

\begin{tabular}{|c|c|c|c|}
\hline Variables & Description & Hypothesised effect & Source \\
\hline Age & Age of the household head in years & + & Olarewaju (2016) \\
\hline Gender & 1 if male, 2 otherwise & $-/+$ & Chaturuka (2013) \\
\hline Education level & Qualification attained by the sunflower farmer & + & Olarewaju (2016) \\
\hline Household size & Number of household members & + & Olarewaju (2016) \\
\hline Household labour size & Members who provide labour for sunflower production & $-/+$ & Olarewaju(2016) \\
\hline Off-farm Activity & Off-farm activities of the household (IGAs) & $-/+$ & Chaturuka (2013) \\
\hline Land holding & Total acreage of land per household & + & Olarewaju (2016) \\
\hline Land cultivated under sunflower & Total acreage available for sunflower production & + & Olarewaju (2016) \\
\hline Proximity to mini stores & Distance from production site to the bulking store for the sunflower & + & Chaturuka (2013) \\
\hline Extension visits/ services & Number and purpose of extension contacts to sunflower producers & + & Olarewaju (2016) \\
\hline Access to inputs & Inputs used in sunflower production such as seed, fertiliser, chemical if any & + & Rocca (2014) \\
\hline Seed cost & How much is spent on buying seed & + & Rocca (2014 \\
\hline Access to credit & Utilisation of credit from other sources other than contract farming & _ & Olarewaju (2016) \\
\hline Sunflower Farming Experience & Years spent producing sunflower as an enterprise & + & Chaturuka (2013) \\
\hline Selling Price & Price at which sunflower is sold per kg & + & Olarewaju(2016) \\
\hline
\end{tabular}


TABLE 2. Factors influencing participation in contact farming (logistic estimates) in sunflower production in northern Uganda

\begin{tabular}{lrrrr}
\hline Variables & Logit coefficient & P-value & $\begin{array}{r}\text { Marginal effect } \\
\text { coefficient }\end{array}$ & P-value \\
\hline Age & $0.027 *(0.015)$ & 0.073 & $0.007 *(0.004)$ & 0.072 \\
Education level & $0.305(0.477)$ & 0.522 & $0.075(0.117)$ & 0.523 \\
Gender & $0.163(0.365)$ & 0.656 & $0.040(0.090)$ & 0.657 \\
Off-farm activity & $-0.621 *(0.368)$ & 0.091 & $-0.150^{*}(0.087)$ & 0.084 \\
Access to credit & $-1.336^{* * *}(0.469)$ & 0.004 & $-0.291 * * *(0.085)$ & 0.001 \\
Extension visits & $0.431(0.357)$ & 0.226 & $0.106(0.087)$ & 0.224 \\
Experience in sunflower & $0.800^{* * *(0.210)}$ & 0.000 & $0.196 * * *(0.052)$ & 0.000 \\
Household size & $1.250^{* *}(0.471)$ & 0.008 & $0.306 * *(0.116)$ & 0.008 \\
Distance to mini store & $-0.180 *(0.098)$ & 0.066 & $-0.044 *(0.024)$ & 0.067 \\
Seed access & $-0.481(0.483)$ & 0.319 & $-0.115(0.112)$ & 0.304 \\
Seed cost & $-0.559(0.468)$ & 0.232 & $-0.137(0.114)$ & 0.230 \\
Unit price & $0.086(0.060)$ & 0.153 & $-3.598^{* * *}(0.704)$ & 0.000 \\
Land holding & $-14.678^{* * *}(2.882)$ & 0.000 & $0.021(0.014)$ & 0.148 \\
Acreage under sunflower & $0.782 * * *(0.195)$ & 0.000 & $0.192^{* * *}(0.047)$ & 0.000 \\
& & & & \\
Model characteristics & & & & \\
Number of observation & 300 & & & \\
LR chi2(15) & 144.97 & & & \\
Pseudo & $\mathrm{R} 2$ & 0.3486 & & \\
Log likelihood & -135.46 & & & \\
P- value & 0.0000 & & & \\
\hline
\end{tabular}

Significant at: $* 10 \%, * * 5 \%, * * * 1 \%$ levels; Figures in parentheses are standard errors

acreage under sunflower production were significant. The logit regression model fits the data with a $135.46 \%$ prediction of contracted and non-contracted (Table 2).

Age of the household head significantly and positively influenced $(\mathrm{P}<0.1)$ sunflower contract farming participation; whereby an increase in the age of household head by one year increased the probability of participating in the sunflower contract farming by $0.7 \%$; all other factors held constant. This means the older the farmer was, the higher the probability of participation in sunflower contract farming. The positive sign for the age variable could be understood from the commonly observed positive correlation between the age and production experience. In other words, older farmers tend to be more willing to engage in contract than their younger counterparts. These results are consistent with Sambuo (2014), who found that age coefficient had a significant positive coefficient with the participation in tobacco contract farming. This implied that with increase in age farmers tend to produce sunflower under contract and abandon producing outside contract for more demanding cropping systems with high transactional cost associated with them.

Engagement in off-farm activity reduced farmer participation $(\mathrm{P}<0.1)$ in sunflower contract farming by $15 \%$ (Table 2 ). This was attributed to the possibility that off-farm activity conflicted with contractual sunflower production in terms of time that a sunflower farmer could have allocated to production under contract. These results are consistent 
with those of Musara et al. (2011), who found that farmers who were the high-income earners easily mobilised productive resources and were more diversified than farmers who were the low-income earners. However, Beyene (2008) argues that the majority of farmers receiving off-farm income, use it for their consumption, while very few use the offfarm income for investment in farms.

Access to credit was significant $(\mathrm{P}<0.01)$ and had a negative coefficient; whereby unit increase of access to credit reduced participation in sunflower contract farming by $29.1 \%$ (Table 2). Whenever a farmer had access to credit, he/she tended to invest in other enterprises such as livestock instead of engaging in sunflower production. As a result, this limited their chances of participation in sunflower contract farming. This finding is similar to the report by Chaturuka (2013) and Sambuo (2014), that as farmers obtained alternative sources of financing for their tobacco farming, they were less likely to participate in contract farming.

Sunflower production experience was significant $(\mathrm{P}<0.01)$ and had a positive coefficient (Table 2). According to the results, a unit increase in sunflower farming experience increased participation in contract farming by $19.6 \%$. The more years a farmer took in producing sunflower, the better he/she got exposed to terms of contract farming; and the better the chances of being able to participate in contract farming. This study agreed with that of Saigenji (2010), which revealed that the more knowledgeable farmers were in tea production, the more they were aware of the advantages of participating in a contract; and therefore the more they would join contract farming. Other studies whose results conformed with the present study included Okoye et al. (2009) and Tarawali et al. (2012), who reported that farming experience positively influenced participation in farming contracts, implying as a farmer adds on years of production in sunflower chances of participation in contract farming increases.
Household size was also significant $(\mathrm{P}<$ 0.01 ) and had a positive coefficient (Table 2). Thus, an increase by one member of the family increased the probability of participation in contract farming by $30.6 \%$, all other factors held constant. A possible explanation to this could be that farmers with large household sizes tend to have the opportunity to grow large tracts of sunflower with adequate financing from contractors as it is the case in Oyam district. This finding conforms to results of earlier studies on contract farming (Chaturuka, 2013; Kokeyo, 2013), that bigger household sizes were more likely to engage in sunflower contract farming by $30.6 \%$, compared to their other small counterparts. This may imply that households with large family sizes found it cheaper to use family labour for sunflower growing than their counterparts with small family sizes.

Distance to mini-stores (bulking centres) was also significantly $(\mathrm{P}<0.1)$ associated with a decreasing probability of the decision to participate in contract farming (Table 2). This negative relationship implies that if the distance between the farm and the mini-store area was substantial, farmers tended to be discouraged to participate in sunflower contract farming. The nearer the bulking stores to the sunflower contract farmers, the more likely farmers were to participate in contract farming. For instance, a one-kilometre reduction in distance to mini-stores from a sunflower farmer's location, increased participation in sunflower contract farming by $4.4 \%$. This could be due to the reason that contracting companies found it easier to buy sunflower produce bulked at specified bulking points/mini-stores, rather than from individual farm gates that may attract more additional transactional costs. This study concurs with the earlier findings of Eneyew (2012), who also reported a negative relationship between distance to market and participation; whereby the further the distance to the milk collection centre, the less likelihood of farmer participation in contract farming (Ntaganira et al., 2017). 
Selling price was also significant $(\mathrm{P}<0.01)$ and had a negative coefficient (Table 2). The study showed that participation in contract farming was influenced by selling price of sunflower; whereby a $1 \%$ decline in the selling price reduced participation in sunflower contract farming by $359.8 \%$. This can be because the farmers opt for producing other crop enterprises which fetch better selling prices than contracting in sunflower production. Contrary to this result, Ntaganira et al. (2017) observed that price of milk per litre positively influenced participation in dairy contact farming; implying that if contractors are offering fair prices compared to prices in the open market, the likelihood of participation in contract increases.

Land allocated to sunflower production had a significant $(\mathrm{P}<0.01)$ positive influence on participation in sunflower contract farming (Table 2). Famers who allocate an additional acre of land for production to sunflower were more likely to engage in sunflower contract farming by $19.2 \%$, implying farmers who allocate more land or have relatively huge amounts of money for hiring more acreages of land for production under contract are likely to participate in contract farming. As a prerequisite for joining contract farming, companies that engaged sunflower farmers in contract farming, needed a minimum of at two hectares for one to be engaged in contract farming.

This finding was similar to that of Kokeyo (2013), that land was a very important determinant in recruiting farmers to participate in contract farming. This result, however, is somewhat contradictory to those of Eneyew (2012) and Kuwornu et al. (2014), who found strong evidence of the negative effect of farm size on likelihood participation. In this case, smallholder farmers with large farm sizes tended to move their objectives towards participation in contract farming. Large farm size also implied that farmers could diversify into other crops, which reduced the inherent risk often associated with agricultural production, and which is further compounded by contract farming.

\section{CONCLUSION}

The results show that sunflower production experience $(\mathrm{P}<0.01)$, access to credit $(\mathrm{P}<0.01)$, unit produce price $(\mathrm{P}<0.01)$, and acreage under sunflower production $(\mathrm{P}<0.01)$ are the main factors that significantly influence the participation in sunflower contract farming. Other factors which influence participation in sunflower contract farming included: household size and household size labour force $(\mathrm{P}<0.05)$, age $(\mathrm{P}<0.1)$, off-farm activity $(\mathrm{P}<0.1)$, distance to mini store $(\mathrm{P}<0.1)$. Collaborative efforts by all parties engaged in contracting arrangements are necessary to negotiate a minimum price with the farmers, with a possibility to re-negotiate whenever the market price is above the set price. The study pointed out that improvement in rural roads to enhance taking produce to mini-store is vital in driving sunflower contract farming in Oyam district.

\section{ACKNOWLEDGMENT}

Authors acknowledge the immense contribution of research assistants and respondents in this study. Gratitude also goes to family; friends and relatives who contributed spiritually and financially towards making this study a success.

\section{REFERENCES}

Babatunde, R.O. and Qaim, M. 2009. Patterns of income diversification in rural Nigeria: Determinants and impacts. Quarterly Journal of InternationalAgriculture 48(4): 305.

Beyene, A.D. 2008. Determinants of off-farm participation decision of farm households in Ethiopia. Agrekon 47(1):140-161. doi:10.1080/03031853.2008.9523794. 
Boniphace, N.S., Fengying, N. and Chen, F. 2014. An analysis of factors affecting smallholder rice farmers. Level of sales and market participation in Tanzania: Evidence from National Panel Survey Data 2010 2011 5(23):185-205.

Chaturuka, S. 2013. Determinants of smallholder tobacco contract farming participation in Zimbabwe. MSc. Dissertation. Department of Economics, University of Zimbabwe, Zimbabwe. 66pp

Eaton, C. and Shepherd, A. 2001. Contract Farming: Partnerships for growth. Agricultural Services Bulletin 165. Rome, Italy: Food and Agriculture Organization of the United Nations. Retrieved from http:// www.fao.org/docrep/004/Y0937E/v0 937eOO.HTM on 15th February 2019.

Elepu, G. and Nalukenge, I. 2009. Contract farming, smallholders and commercialization of agriculture in Uganda: The case of sorghum, sunflower, and rice contract farming schemes. CEGA Working Paper Series No. AfD-0907. Center of Evaluation for Global Action. University of California, Berkeley. USA.

Eneyew, A. 2012. Determinants of livelihood diversification in pastoral societies of Southern Ethiopia. Journal of Agriculture and Biodiversity Research 1(3):43-52.

Dubbert, C. 2019. Participation in contract farming and farm performance: Insights from cashew farmers in Ghana. pp. 749763. doi: 10.1111/agec.12522.

FAO, 2001. Contract farming partnership for growth. Eaton, C., Shepherd, A.W. (Eds.). FAO Agricultural Service Bulletin No. 145, Rome, Italy.

Kagwiria, F. 2017. Factors influencing contractual farming in Kenya. A case of Buuri Constituency, Meru County, Kenya.

Kokeyo, P.L. 2013. An assessment of the factors affecting contract farming: The case of sugarcane production in Migori county, Kenya. MSc. Thesis. University of Nairobi, Kenya. 74pp.
Kuwornu, J.K.M., Bashiru, M. and Dumayiri, M. 2014. Farm households' livelihood diversification into agroprocessing and nonagro-processing activities: Empirical evidence from Ghana. Information Management and Business Review 6(4):191-199.

Minot, N. 2011. Contract farming in Africa: Opportunities and challenges. Presented at the AAMP Policy Seminar "Successful Smallholder Commercialization" 22 April 2011 Lemigo Hotel, Kigali, Rwanda.

Musara, J.P., Zivenge, E., Chagwiza, G., Chimvuramahwe, J. and Dube, P. 2011. Determinants of smallholder cotton contract farming participation in a recovering economy: Empirical results from Patchway district, Zimbabwe. Journal of Sustainable Development in Africa 13: (4): 9

Ntaganira, E. 2017. Determinants of participation in contract farming among small holder diary farmers in Rwanda, International Journal of Thesis Projects and Dissertations 5(3):11-19. Available at: www.researchpublish.com.

Okoye, B.C. 2009. Adoption scale analysis of improved cocoyam production, processing and storage technologies across gender in Enugu North Agricultural Zone of Enugu State, Nigeria. St Louis, MI: IDEAS.

Olaraewaju, O.O. 2016. Analysis of contractual arrangement between sorghum producers and industrial buyers in Kaduna state, Nigeria. MSc. Dissertation. Ahmadu Bello University, Nigeria. 49pp.

Opoku, S.M. 2012. Logistic analysis of factors motivating smallholder farmers to engage in contract farming arrangements with processing firms in Ghana. Journal of Biology, Agriculture and Health care 3208:58-74.

Pandey, A.P. 2016. Socio-economic factors of contract farming: A logistic analysis. IRAInternational Journal of Management \& Social Sciences 3(3):758-760. doi: http:// dx.doi.org/10.21013/jmss.v3.n3.p31. 
Pannell, D.J. 2003. Uncertainty and adoption of sustainable farming systems uncertainty and adoption of sustainable farming systems. SlowAdopAARes3.doc 16/2/99, 1-13.

Prowse, M. 2012. Contract farming in developing countries: Areview. Antwerp, Belgium: Institute of Development Policy and Management, University of Antwerp.

Rocca, V. 2014. The gendered implications of the expansion in commercial sugarcane production: A case study of contract farming in Magobbo, Zambia. MSc.Thesis. Carleton University Ottawa, Ontario, Canada. 62pp.

Saigenji, Y. 2010. Contract farming and its impact on production efficiency and rural household income in the vietnamese tea sector. Ph.D. Dissertation, Department of Rural Development Theory and Policy, University of Hohenheim, Kagoshima, Japan. 86pp.

Sambuo, D. 2014. Tobacco contract farming participation and income in Urambo; Heckma's Selection Model. Journal of Economics and Sustainable Development I5(28):233-234.

Sarmah, B.K. and Chakrabarty, D. 2016. Construction of a table of three-digit random numbers. International journal of Current Research 8(03):28425-28431.
Simtowe, F.P. 2010. Livelihoods diversification and gender in Malawi. African Journal of Agricultural Research 5(3):204-216.

Siros, T. 2013. Cassava smallholders' participation in contract farming in NakhonRatchasrima Province, Thailand. Journal of Social and Developemnt Sciences, AMH International 4(7):332-338.

Tarawali, G. 2012. Commercial scale adoption of improved cassava varieties: A baseline study to highlight constraints of large-scale cassava-based agro-processing industries in Southern Nigeria. Journal of Food, Agriculture \& Environment, 10(3\&4), 689694.

UBOS. 2017. The National population and housing census 2014 - Main Report. Kampala: Uganda Bureau of Statistics, Ministry of Finance and Economic Development, Government of Uganda, Kampala, Uganda.

Wainaina, P.W., Okello, J. and Nzuma, J. 2012. Impact of contract farming on smallholder poultry farmers' income in Kenya. Selected paper prepared for presentation at the International Association of Agricultural Economists (IAAE) Triennial Conference, Foz do lguaqu, Brazil, 18-24 August, 2012. 